\title{
Evaluación de tratamientos de hidrofugación aplicados a piedras de catedrales andaluzas. II. Ensayo de cristalización de sales
}

\section{Evaluation of water repellent treatments applied to stones used in andalusian cathedrals. II. Salt crystallization test}

VILLEGAS SÁNCHEZ, R.; VALE PARAPAR, J.F.
Dpto. Ingeniería Química y Ambiental. Esc. Sup. Ingenieros Industriales. Univ. Sevilla ESPAÑA

\section{RESUMEN}

En un artículo anterior se han evaluado los cambios producidos en las propiedades relacionadas con el acceso y movimiento de agua en la piedra como consecuencia de la aplicación de tratamientos de hidrofugación.

En este trabajo se compara la resistencia a la alteración producida por sales de las probetas tratadas y sin tratar, sometiéndolas al ensayo de cristalización de sulfato sódico.

Tras finalizar el ensayo (75 ciclos) se han medido nuevamente las propiedades relacionadas con el agua, con objeto de comprobar si los tratamientos han sufrido alguna alteración y si mantienen sus características hidrófugas.

\begin{abstract}
$S \cup M M A R Y$
In a previous paper we have studied the changes that have ocurred in the properties related to water access and movement in the stone after the application of water repellent treatments.
\end{abstract}

In this work we compare the weathering resistance of treated and untreated samples by means of sodium sulphate crystallization test.

After finishing the test ( 75 cycles) properties related to water have been measured again to know if the treatments have undergone any kind of deterioration and lose their water repellent characteristics.

\section{INTRODUCCIÓN}

Se han estudiado cinco piedras calizas que pueden considerarse representativas de las utilizadas en los monumentos de la región andaluza. Las características principales de las mismas se presentan en la Tabla I.

En la primera parte de este estudio (1) se han medido las propiedades relacionadas con el acceso y el movimiento del agua en la piedra: porosidad abierta, ángulo de contacto, tiempo de absorción de gotas, absorción por capilaridad e inmersión y velocidad de secado. Todos estos valores se ven lógicamente modificados tras la aplicación de los tratamientos.

Se han elegido seis productos hidrófugos que han sido aplicados por inmersión de las probetas en ellos. Sus características y concentraciones se indican en la Tabla II.

\section{INTRODUCTION}

Five types of limestone, that can be considered representative of those used in the monuments of Andalucia have been studied. Their main characteristics are shown on Table I.

In the first part of this study (1) properties related with access and movement of water in stone have been studied: open porosity, contact angle, time for drop absorption, capillarity and inmersion water absorption and water drying rate. All these values are modified after the application of the treatments.

Six water repellent products, whose characteristics and concentrations are shown on Table II, have been applied by inmersion of the samples. 
TABLA I

Características de las piedras

\begin{tabular}{|c|c|c|c|c|c|c|}
\hline \multirow{2}{*}{ Piedra } & \multirow{2}{*}{ Catedral } & \multirow{2}{*}{ Tipo } & \multicolumn{2}{|c|}{ Comp. med. \% } & \multicolumn{2}{|c|}{$\%$ Porosidad } \\
\hline & & & $\mathrm{SiO}_{2}$ & $\mathrm{CaCO}_{3}$ & Macro & Micro \\
\hline Pto de Santa María & Sevilla & Calcarenita & 30 & 67 & 27 & 8 \\
\hline Espera & Sevilla & Caliza & 10 & 85 & 11 & 17 \\
\hline Ubeda & Baeza & Calcarenita & 30 & 65 & 20 & 8 \\
\hline Granada & Granada & Caliza & 3 & 95 & 19 & 6 \\
\hline \multirow{2}{*}{ Almería } & \multirow{2}{*}{ Almería } & \multirow{2}{*}{ Caliza dolomítica } & 7 & 53 & \multirow{2}{*}{17} & \multirow{2}{*}{27} \\
\hline & & & \multicolumn{2}{|c|}{$38 \% \mathrm{MgCO}_{3}$} & & \\
\hline
\end{tabular}

TABLE I

Characteristics of the stones

\begin{tabular}{|c|c|c|c|c|c|c|}
\hline \multirow{2}{*}{ Stone } & \multirow{2}{*}{ Cathedral } & \multirow{2}{*}{ Type } & \multicolumn{2}{|c|}{ Av. Comp., \% } & \multicolumn{2}{|c|}{$\%$ Porosity } \\
\hline & & & $\mathrm{SiO}_{2}$ & $\mathrm{CaCO}_{3}$ & Macro & Micro \\
\hline Pto de Santa María & Sevilla & Calcitic sandstone & 30 & 67 & 27 & 8 \\
\hline Espera & Sevilla & Limestone & 10 & 85 & 11 & 17 \\
\hline Ubeda & Baeza & Calcitic sandstone & 30 & 65 & 20 & 8 \\
\hline Granada & Granada & Limestone & 3 & 95 & 19 & 6 \\
\hline \multirow{2}{*}{ Almería } & \multirow{2}{*}{ Almería } & \multirow{2}{*}{ Dolomitic limestone } & 7 & 53 & \multirow{2}{*}{17} & \multirow{2}{*}{27} \\
\hline & & & \multicolumn{2}{|c|}{$38 \% \mathrm{MgCO}_{3}$} & & \\
\hline
\end{tabular}

TABLA II

Productos de tratamiento aplicados

\begin{tabular}{|l|l|l|l|}
\hline \multicolumn{1}{|c|}{ Producto } & \multicolumn{1}{|c|}{ Fabricante } & \multicolumn{1}{c|}{ Comp. del agente activo } & \multicolumn{1}{c|}{ Dilución } \\
\hline BS 28 & Wacker & Organosilícico (el fabricante no especifica más) & $5 \%$ en Xileno \\
$290 \mathrm{~L}$ & Wacker & Organosiloxano oligómero & $5 \%$ en Xileno \\
Baysilone & Bayer & Resina de silicona & $5 \%$ listo para usar \\
Tegosivin HL100 & Goldschmidt & Organosilícico monómero & $10 \%$ en Xileno \\
Consolidante 55050 & Ard Raccanello & Resina acrilsilicónica & $10 \%$ listo para usar \\
Paraloid B72 & Röhm \& Haas & Copolímero de metacrilato y etilmetacrilato & $10 \%(\mathrm{p} / \mathrm{v})$ en $1,1,1$ tricloroetano \\
\hline
\end{tabular}

TABLE II

Treatment products applied

\begin{tabular}{|l|l|l|l|}
\hline \multicolumn{1}{|c|}{ Product } & \multicolumn{1}{|c|}{ Company } & \multicolumn{1}{c|}{ Activ agent } & Dilution \\
\hline BS 28 & Wacker & Organosilicone (nothing else specified) & $5 \%$ in Xylen \\
$290 \mathrm{~L}$ & Wacker & Oligomeric Organosiloxane & $5 \%$ in Xylen \\
Baysilone & Bayer & Silicone resin & $5 \%$ ready to use \\
Tegosivin HL100 & Goldschmidt & Monomeric organosilicic & $10 \%$ in Xylen \\
Consolidante 55050 & Ard Raccanello & Acrylsiliconic resin & $10 \%$ ready to use \\
Paraloid B72 & Röhm \& Haas & Metacrylate and etilmeta-crylate copolymer & $10 \%(w / v)$ in 1,1,1 tricloroetane \\
\hline
\end{tabular}


De los resultados obtenidos en este estudio puede destacarse que los dos productos acrílicos, en comparación con los organosilícicos, originan menores disminuciones en los valores relacionados con la absorción de agua y a la vez causan una mayor disminución en la velocidad de secado, por lo que puede esperarse que tengan peor comportamiento en lo que se refiere a mejorar la resistencia a la alteración de las muestras.

En este trabajo se determina esta resistencia a la alteración producida por las sales, utilizando el ensayo de cristalización de sulfato sódico; tras dicho ensayo, se han evaluado las propiedades hidrófugas de aquellas probetas que han permanecido inalteradas.

\section{ENSAYO DE CRISTALIZACIÓN DE SULFATO SÓDICO}

La cristalización de sales, sea cual sea el origen de éstas, puede considerarse la causa más frecuente de aiteraciones.

El sulfato sódico, que es el compuesto más frecuentemente empleado en este ensayo, se caracteriza por un elevado volumen molecular, que se ve aún mas incrementado por el hecho de cristalizar a temperatura ambiente con diez moléculas de agua. Durante la fase de secado en estufa se produce la cristalización del sulfato en forma de sal anhidra, tanto en el interior como en el exterior de la probeta. Este fenómeno provocará tensiones que pueden llegar a causar la pérdida de cohesión de los granos. Al introducir las probetas en la solución se hidrata la sal, aumentando de volumen, y finalmente se disuelve; es entonces cuando los granos, debilitados por la cristalización e hidratación, terminan por desprenderse.

El ensayo ha estado formado por 75 ciclos consistentes en:

- 24 horas de inmersión total en solución de sulfato sódico al $10 \%$ a temperatura ambiente,

- 21 horas de secado en estufa a $65^{\circ} \mathrm{C}$,

- 3 horas para enfriamiento y pesada.

Se ha limitado la temperatura de secado a $65^{\circ} \mathrm{C}$, teniendo en cuenta que los productos de tratamiento pueden sufrir alguna alteración a temperaturas más elevadas; este valor, relativamente bajo, ha obligado a alargar el tiempo de secado para asegurar la eliminación del agua, ajustándose, por ello, la duración del ciclo a 48 horas.
Form the results obtained in this study, it may be pointed out that the two acrylic products, in comparison with organosilicic ones, have caused a lesser decrease in values related to water absorption and, at the same time, a greater decrease on the water drying rate so that it can be thought that their effect on the weathering resistance of the samples is worse.

In this work we determine this resistance to the deterioration due to salt crystallization, using the sodium sulphate crystallization test; after this test we have measured the water repellency of the unaltered samples.

\section{SODIUM SULPHATE CRYSTALLIZATION TEST}

Salt crystallization, whatever its origin, can be considered as the most frequent cause of aiteration of the stone.

Sodium sulphate, used in this test, is characterized by a high molecular volume due also to crystallize at ambient temperature with ten molecules of water. During the oven drying period the sulphate crystallizes on the form of anhidrous salt, on the inner and outer part of the sione. This fact will cause tensions that can origin the loss of cohesion of the mineral grains. When the samples are introduced on the solution the salt becomes hydrated, increasing its volume, and finally it disolves; now the mineral grains, weakened by the crystallization and hydration of the salt, finally fall down.

This test has been formed by 75 cycles consisting on:

- 24 hours of total inmersion in the $10 \%$ sodium sulphate solution at ambient temperature,

- 21 hours for drying in oven at $65^{\circ} C$,

- 3 hours for cooling and weighing.

The drying temperature has been limited to $65^{\circ} \mathrm{C}$ to avoid any damage on the treatment products caused by higher temperatures; this relatively low value has made necessary to extend the drying time to reach the total evaporation of water; finally we have adjust the total duration of the cycle to 48 hours. 
El seguimiento del ensayo ha consistido básicamente en la pesada de las probetas y la observación visual de las alteraciones. Aquellas probetas que, tras un determinado número de ciclos, han alcanzado un grado de deterioro considerable se han ido retirando del ensayo.

\section{RESULTADOS DEL ENSAYO DE CRISTALIZACIÓN}

\subsection{Probetas sin tratar}

A lo largo de un ensayo de cristalización, las probetas comienzan a ganar peso en los primeros ciclos, debido a la incorporación de sales. Posteriormente se producen alteraciones que se manifiestan en la pérdida de material de la superficie, con morfología diferente según las características de cada piedra.

Las probetas de Puerto de Santa María, Ubeda y Granada experimentan la caída de partículas, de forma homogénea en toda la superficie, quedando redondeadas las aristas y los vértices. Por el contrario, las de Espera y Almería, más heterogéneas en cuanto a estructura física (textura y porosidad), se alteran irregularmente y el desprendimiento de material tiene lugar con formación de huecos en determinados puntos de la superficie, manteniéndose en muchos casos aristas y vértices.

Esta pérdida de material lleva consigo una disminución de peso de las probetas, como se recoge en la figura 1, en la cual cada una de las curvas representa valores medios de cuatro probetas.

En las figuras 2 y 3 se observa el aspecto de probetas de Granada y Almería tras 10 ciclos, poniéndose de manifiesto la diferente morfología de la alteración de cada una de ellas. Estas diferencias se observan también en las alteraciones presentes en monumentos construidos con estos tipos de piedra.

\subsection{Probetas tratadas}

Los tratamientos hidrófugos, al disminuir la entrada de agua en la piedra, mejoran su respuesta frente a los agentes de alteración. Las probetas tratadas resisten mayor número de ciclos sin alterarse, llegando en numerosas ocasiones al final del ensayo (75 ciclos) sin ningún deterioro.

En las figuras 4 a 8 se recogen las curvas de evolución de peso de las probetas de cada tipo
During the test we have weighed the samples after each cycle and taken notice of the macroscopic alterations. When the samples become deteriorated in a great extend they have been taken off the test.

\section{CRYSTALLIZATION TEST RESULTS}

\subsection{Untreated samples}

On the two or three first cycles of the test these samples begin to gain weight, due to the salt that remains inside of them. After, the deterioration appears on the form of loss of material from the surface, with different morphology depending on the characteristics of each stone.

The samples of Puerto de Santa María, Ubeda and Granada suffer the fall of particles homogeneously from the whole surface, becoming rounded the edges and tops. On the other side, samples from Espera and Almería, whose physical structure (texture and porosity) is more heterogeneous, are weathered irregularly with the formation of holes on some points of the surface, keeping very often unweathered edges and tops.

This loss of material causes a decrease on the weight of the samples, as it can be seen of Figure 1 , on which each of the curve represents medium values of four samples.

On Figures 2 and 3 appear samples from Granada and Almería after 10 cycles, making clear the different form of deterioration of each of them. These differences can be observed also on the monuments where exist these types of stone.

\subsection{Treated samples}

Water repellent treatments, as they produce a decrease on the quantity of water that goes into the stone, improve the response of the stone to the weathering agents. Treated samples resist high number of cycles before weathering, a lot of them reaching the end of the test without deterioration.

On figures 4 to 8 are shown the weight evolution of the samples of each type of stone. On very 
de piedra con los diferentes tratamientos, observándose que, en muchas de ellas, dicho peso permanece constante, lo cual indica la ausencia de alteraciones importantes en estas probetas. La piedra de Almería, mucho más porosa y con un alto porcentaje de microporos, es más alterable que las demás, como se desprende del hecho de que las probetas tratadas resistan menor número de ciclos.

Los productos acrílicos presentan un comportamiento muy característico. Dado que su efecto hidrófugo disminuye tras un contacto prolongado con el agua (como ha sido observado por diversos autores $(2,3)$ ), después de un número más o menos corto de ciclos (según el tipo de piedra), durante los cuales el peso de las probetas no varía y se mantienen inalteradas, éstas comienzan a absorber solución, experimentando considerables aumentos de peso y progresando la alteración rápidamente. El tipo de alteración es siempre el mismo y consiste en el desprendimiento de placas de espesor variable que dejan al descubierto una nueva superficie arenizada. Este tipo de alteración es típico de tratamientos con baja penetración, ya que las sales se acumulan tras la capa hidrofugada, donde se produce la evaporación del agua. La posterior hidratación de estas sales en la siguiente etapa de inmersión provoca el debilitamiento de esa zona y, por último, la caída de las placas así formadas. En la figura 9 se observa claramente este proceso en dos probetas de Ubeda tratadas con Paraloid B72. Todas las probetas tratadas con este producto (que ha alcanzado profundidades de impregnación muy bajas en todas las probetas) sufren la alteración descrita antes del ciclo 20, como puede deducirse de las curvas de evolución de peso (figuras 4 a 8). Las probetas tratadas con ARD experimentan la misma morfología de alteración, si bien no en todos los casos. En la figura 10 aparece una probeta de Puerto de Santa María tratada con este producto mostrando el típico desprendimiento de placas.

Los productos organosilícicos se comportan bastante mejor, manteniéndose inalteradas numerosas probetas después de haber sido sometidas a los 75 ciclos de cristalización. En los casos en que tiene lugar algún tipo de deterioro, éste se manifiesta, normalmente, con el desprendimiento de algunos trozos aislados, posiblemente debido a la existencia de grietas o fisuras en la piedra que no han sido protegidas efizcamente por el tratamiento.

Además de la alteración macroscópica se ha controlado, al final del ensayo, en aquellas probetas que han permanecido sin alterarse, la much of them, the weight remains constant, fact that points out the absence of important deterioration on these samples. The alterability of Almeria stone, with the highest porosity of all and a great percentage of micropores, is greater, as it can be seen from the fact that treated samples resist lesser number of cycles.

Acrylic products have a very characteristic behaviour. Given that their water repellency decreases after a long period in contact with water (as it has been studied by several authors $(2,3))$, after a certain number of cycles (depending on the type of stone), during which the samples have remained unaltered and their weights without changes, they begin to absorb solution, suffering great increments of weight and becoming weathered very rapidly. The pattern of alteration is always the same and consists on the detachment of sheets from the surface, which leave uncovered a new disgreated surface. This type of deterioration is characteristic of treatments with low penetration, and it's due to the accumulation of salt behind the treated layer, where the evaporation of water takes place. The later hydration of this salt, on the following inmersion phase, causes the weakening of this area and, at last, the falling down of the sheets so formed. On Figure 9 it can be seen clearly this procces on two Ubeda samples treated with Paraloid B72. Every samples treated with this product (which reaches very low penetration depth on all the cases) suffer this type of deterioration before cycle number 20, as it is shown on Figures 4 to 8 . Samples treated with ARD suffer the same weathering but not all of them. On Figure 10 appears a sample from Puerto de Santa María treated with $A R D$, showing the characteristic detachment of the superficial layer.

Organosilicic products have a much better behaviour, with a lot of samples remaining unaltered after the whole test, 75 cycles. When some kind of deterioration appears, it's on the form of the falling of little fragments, posibly due to the previous existence of cracks that have not been protected by the treatment.

After finishing the test, the hydrophobic properties have been measured on the unweathered samples. It has been measured drop absorption 
permanencia de las propiedades hidrófugas. Para ello, se ha medido el tiempo de absorción de de gotas, la absorción por capilaridad y por inmersión y la velocidad de secado. En las figuras 11 a 14 aparecen estos valores para las probetas de Ubeda (tipo de piedra en el que todas las probetas tratadas permanecen sin alterar, excepto las correspondientes a Paraloid B72), comparándolos con los obtenidos antes del ensayo de alteración.

Puede observarse que los valores después del ensayo son muy semejantes a los previos y bastante alejados de los de las probetas sin tratar. Ello pone de manifiesto que los tratamientos han resistido el ensayo sin perder sus características hidrorrepelentes.

\section{CONCLUSIONES}

La alteración de las probetas sin tratar es función de las características de la piedra. En piedras homogéneas, como son las de Puerto de Santa María, Ubeda y Granada, el deterioro se manifiesta con la caída de granos de toda la superficie, llegándose al redondeamiento de las probetas; en piedras de textura heterogénea, como son las de Espera y Almeria, tiene lugar el desprendimiento de granos de zonas localizadas de la probeta.

Los tratamientos hidrófugos mejoran, en general, la resistencia a la alteración de todos los tipos de piedra, si bien pueden hacerse algunas puntualizaciones.

Los productos acrílicos (Paraloid B72 en todos los tipos de piedra y ARD en todos excepto Ubeda y Espera) pierden rápidamente sus características hidrófugas y causan el desprendimiento de la capa superficial tratada.

Los productos organosilícicos protegen totalmente a la mayoría de las probetas y, en los casos en que sufren alteración, ésta es menor que en las probetas no tratadas. Además, las propiedades hidrófugas de las probetas inalteradas se mantienen tras finalizar el ensayo, lo que pone de manifiesto que los tratamientos no se han alterado. time, capillarity and inmersion water absorption, and water drying rate. On Figures 11 to 14 are shown these values for Ubeda samples (on this type of stone every samples, except those treated with Paraloid B72, remains unaltered), together with the same values before the weathering test.

It can be seen that both values are very similar and very much lower than those corresponding to untreated samples. This fact makes it evident that the treatments have resisted the test without losing their hydrophobic properties.

\section{CONCLUSIONS}

The form of weathering of untreated samples depends on the characteristics of stone. For homogeneous stones, such as those from Puerto de Santa Maria, Ubeda and Granada, the deterioration appears like the falling down of grains from all the surface, becoming the samples rounded. On more heterogeneous stones, like Almeria and Espera, it takes place the falling of grains from some areas of the samples.

The water repellent treatments improve, in general, the weathering resistance of every types of stone, although we can point out some facts.

Acrylic products lose quickly their hydrophobic properties and causes the detachment of the treated layer, Paraloid B72 on every types of stone and $A R D$ an all except Ubeda and Espera.

Organosilicic products protect completely the greater part of the samples or, when the samples become weathered, the alteration is lesser than in the untreated ones. Besides, the hydrophobic properties of the unaltered samples remains after finishing the test, making it evident that the treatments have not been deteriorated.

\section{BIBLIOGRAFÍA}

(1) VILLEGAS, R.; VALE, J.F.: Evaluación de tratamientos de hidrofugación aplicados a piedras calizas de Catedrales andaluzas Materiales de Construcción 223, 19-27, 1991.

(2) TABASSO, M.; SANTAMARIA, U.: Consolidant and protective effects of different products on Lecce limestone. Vth Int. Congress on Deterioration and Conservation of Stone. Lausanne, 1985, 697-707.

(3) CHAROLA, A.E.; TABASSO, M.; SANTAMARIA, U.: The effect of water on the hydrophobic properties of an acrylic resin. Vth int. Congress on Deterioration and Conservation of Stone. Lausanne, 1985, 739-747. 


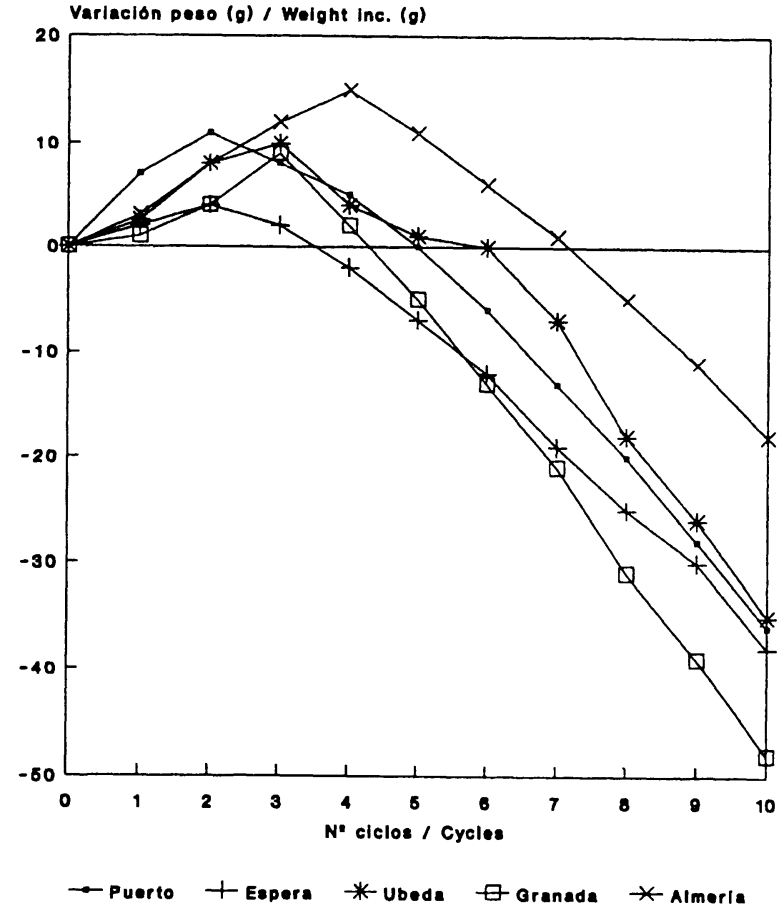

Fig. 1.-Probetas sin tratar.

Fig. 1.-Untreated samples.

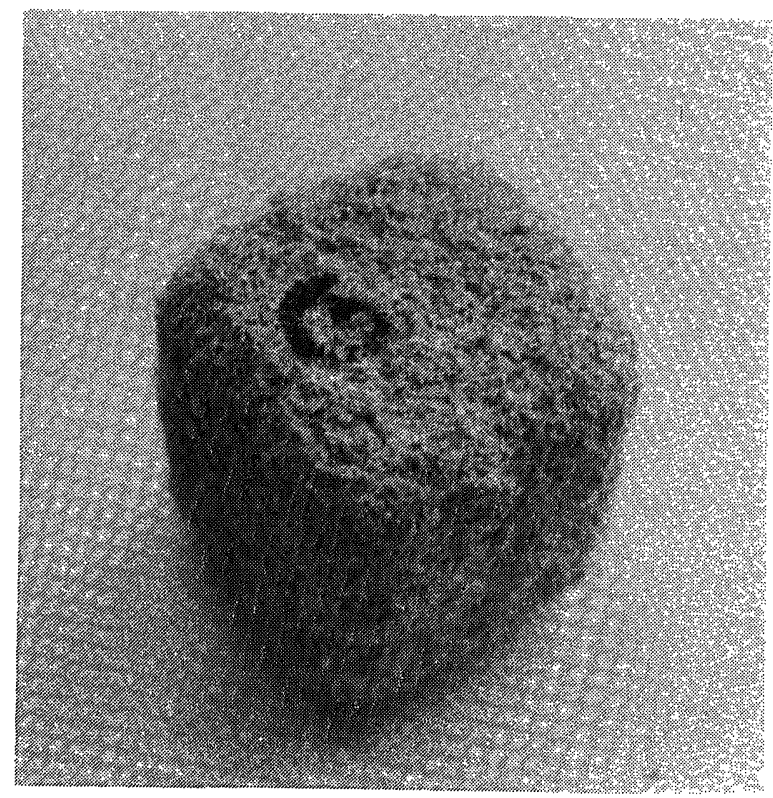

Fig. 2.-Probeta de Granada sin tratar tras 10 ciclos.

Fig. 2.-Untreated Granada sample after 10 cycles.

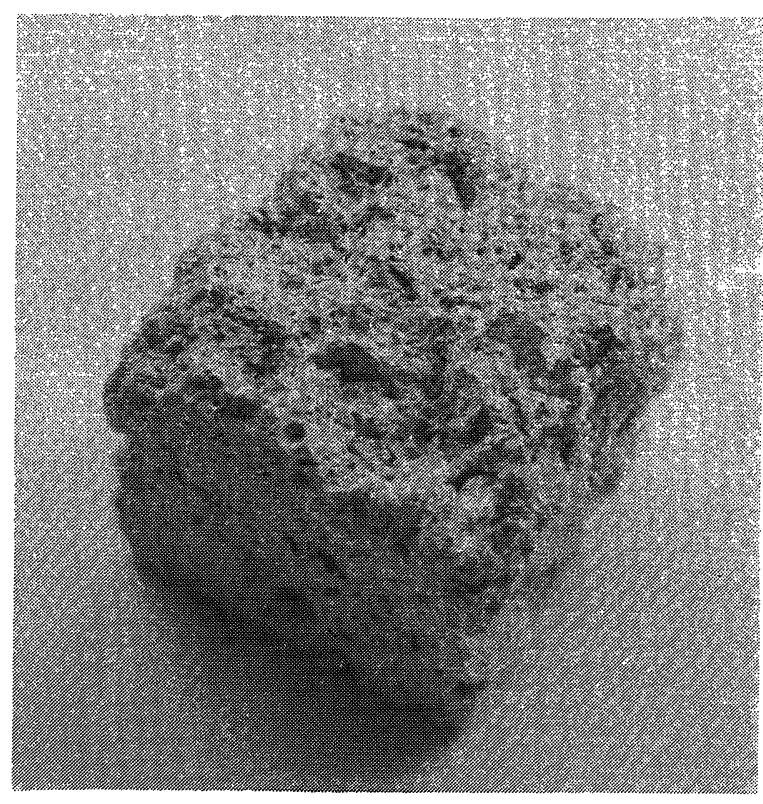

Fig. 3.-Probeta de Almería sin tratar tras 10 ciclos.

Fig. 3.-Untreated Almería sample after 10 cycles.

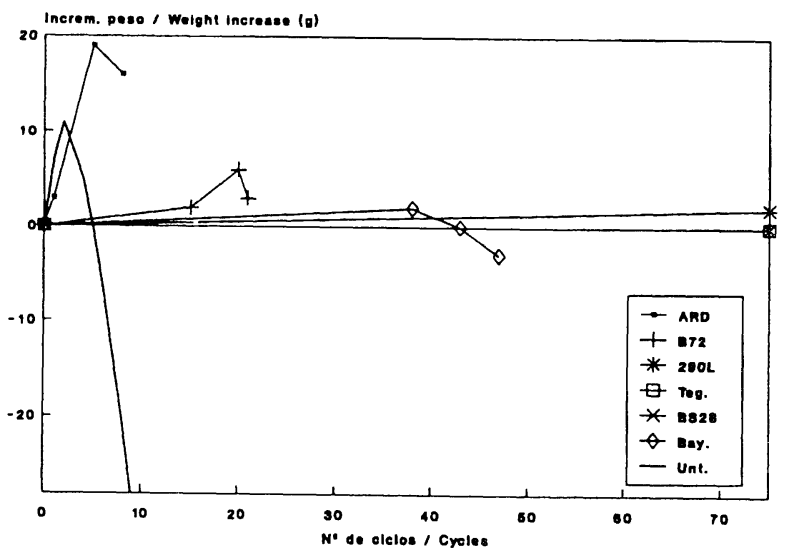

Fig. 4.-Puerto de Santa María.

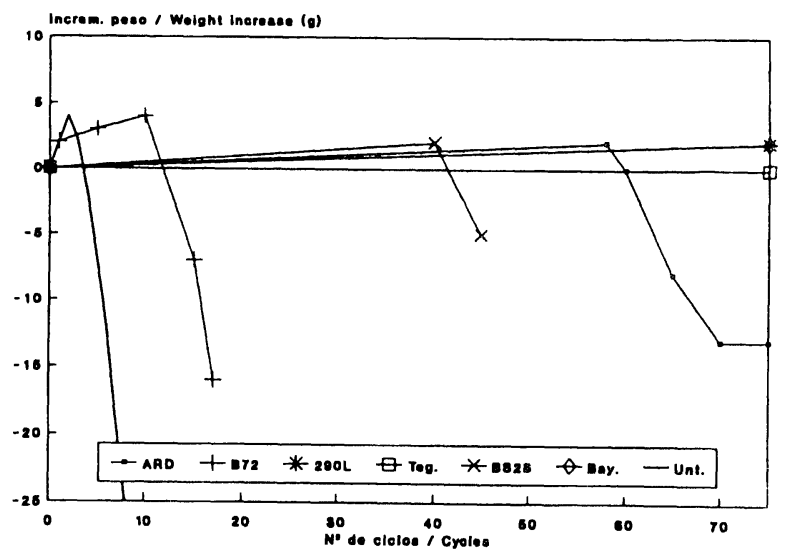

Fig. 5.-Espera. 


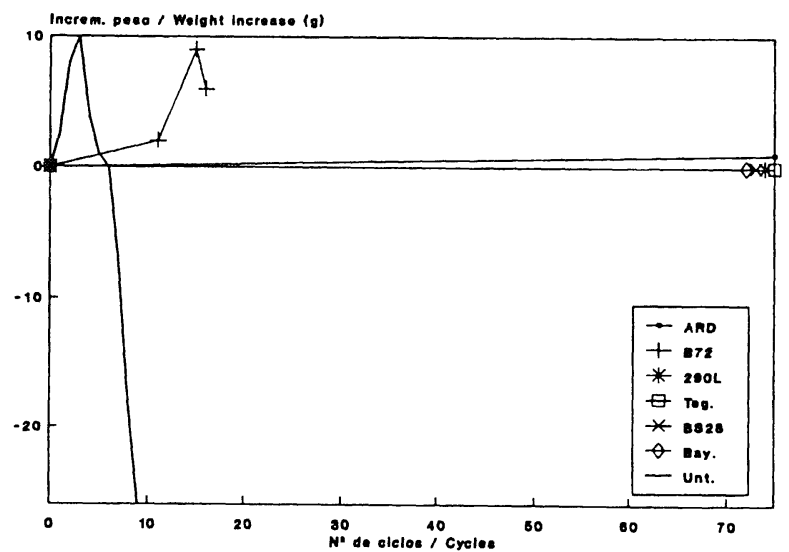

Fig. 6.-Úbeda.

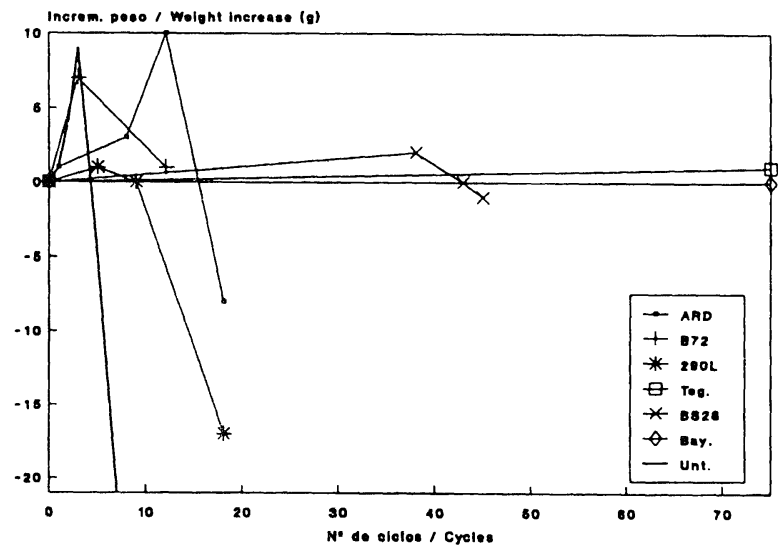

Fig. 7.-Granada.

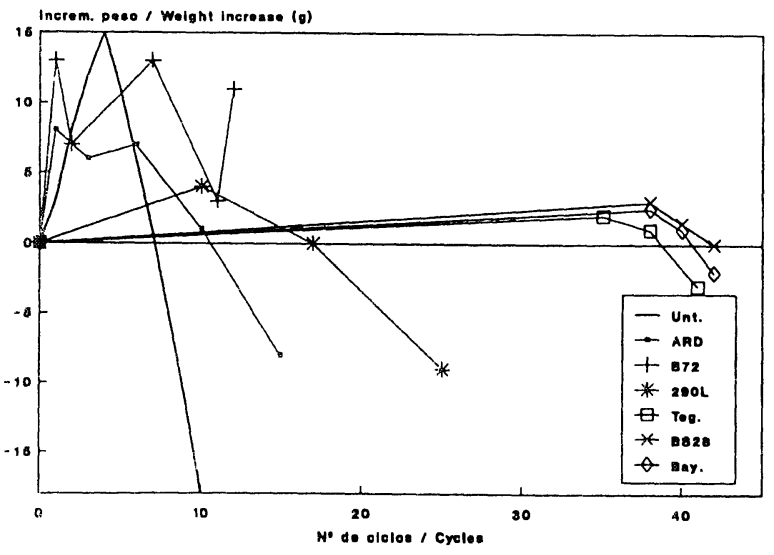

Fig. 8.-Almeria.
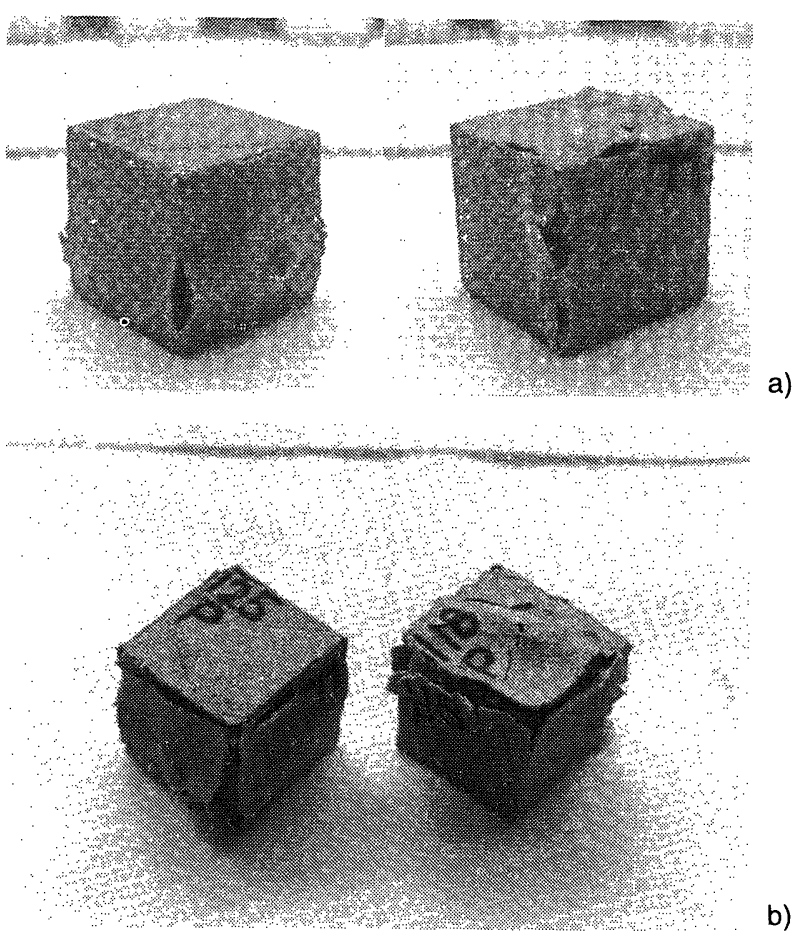

b)

Fig. 9.-Muestras de Úbeda tratadas con Paraloid B72; a) tras 9 ciclos; b) tras 10 ciclos.

Fig. 9. - Úbeda samples treated with Paraloid B72; a) after 9 cycles; b) after 10 cycles.

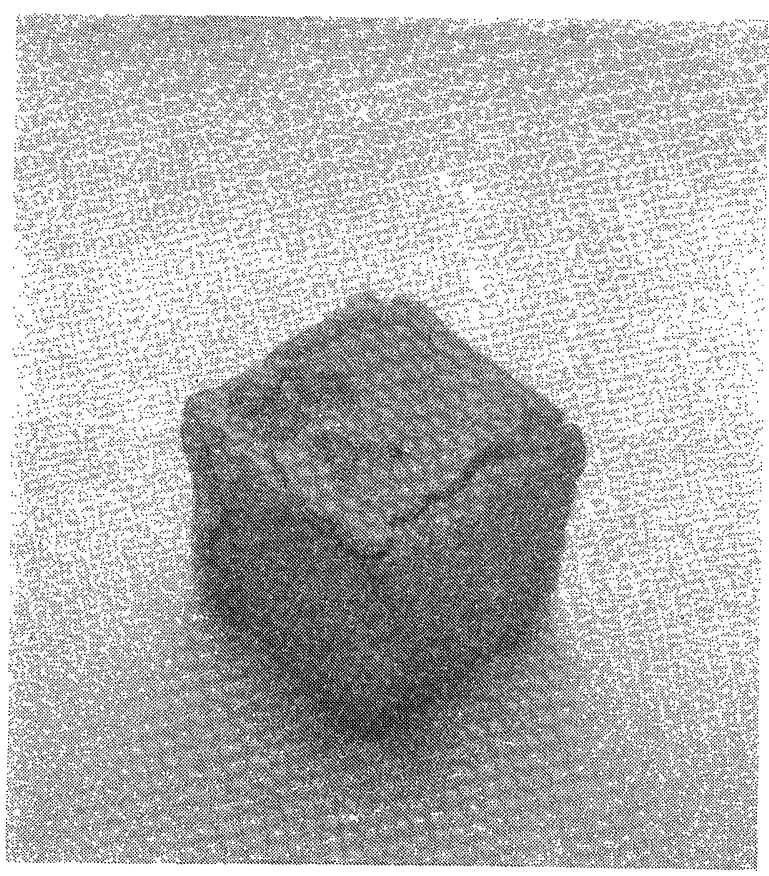

Fig. 10.-Muestra de Puerto de Santa María tratada con ARD tras 10 ciclos.

Fig. 10.- Puerto de Santa Maria sample treated with ARD after 10 cycles.

MATERIALES DE CONSTRUCCIÓN, Vol. 43, n. ${ }^{\circ}$ 230, abril/mayo/junio 1993 


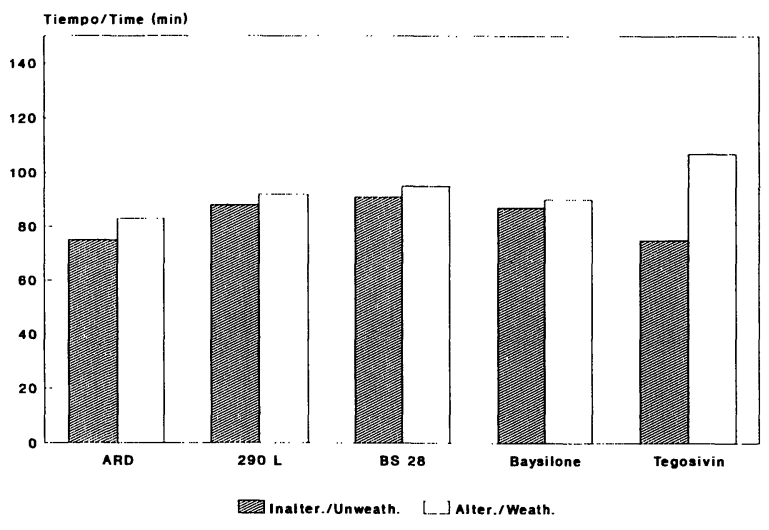

Fig. 11.-Úbeda. Tiempo ABS de gotas.

Fig. 11.-Úbeda. Drop absortion time.

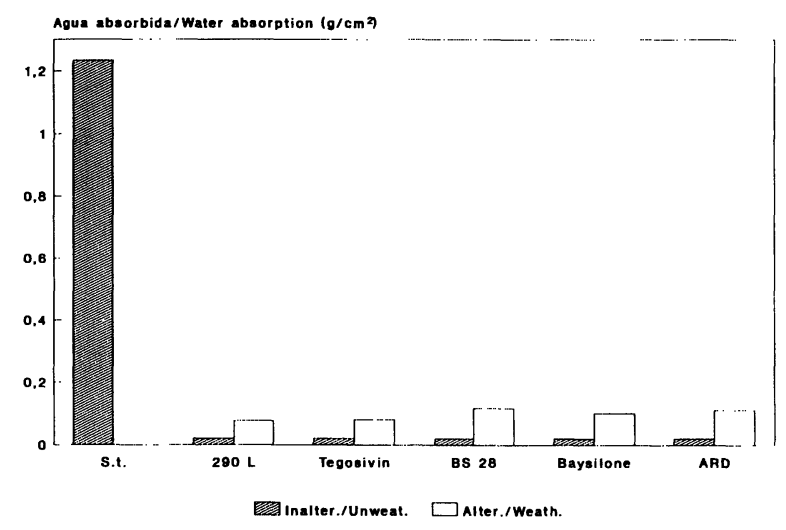

Fig. 12.-Úbeda. Absorción capilar.

Fig. 12.-Úbeda. Capillarity absorption.

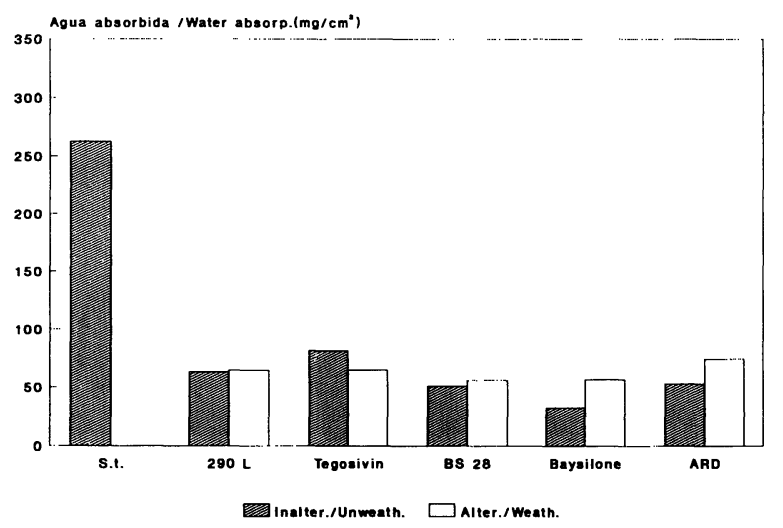

Fig. 13.-Úbeda. Absorción inmersión.

Fig. 13.—Úbeda. Inmersion absorption.

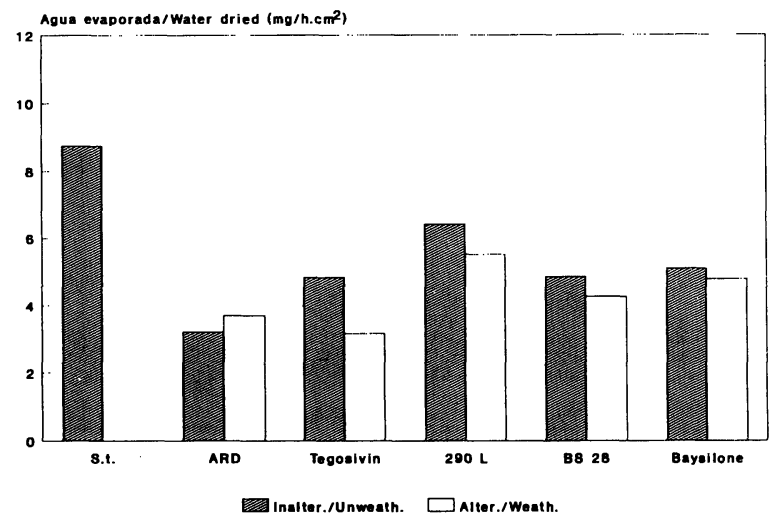

Fig. 14.-Úbeda. Velocidad de secado.

Fig. 14.-Úbeda. Water drying rate. 